\title{
Voluntary reporting on internal control by listed Dutch companies
}

Citation for published version (APA):

Deumes, R. W. J. (2000). Voluntary reporting on internal control by listed Dutch companies. METEOR, Maastricht University School of Business and Economics. METEOR Research Memorandum No. 042 https://doi.org/10.26481/umamet.2000042

Document status and date:

Published: 01/01/2000

DOI:

10.26481/umamet.2000042

Document Version:

Publisher's PDF, also known as Version of record

\section{Please check the document version of this publication:}

- A submitted manuscript is the version of the article upon submission and before peer-review. There can be important differences between the submitted version and the official published version of record.

People interested in the research are advised to contact the author for the final version of the publication, or visit the DOI to the publisher's website.

- The final author version and the galley proof are versions of the publication after peer review.

- The final published version features the final layout of the paper including the volume, issue and page numbers.

Link to publication

\footnotetext{
General rights rights.

- You may freely distribute the URL identifying the publication in the public portal. please follow below link for the End User Agreement:

www.umlib.nl/taverne-license

Take down policy

If you believe that this document breaches copyright please contact us at:

repository@maastrichtuniversity.nl

providing details and we will investigate your claim.
}

Copyright and moral rights for the publications made accessible in the public portal are retained by the authors and/or other copyright owners and it is a condition of accessing publications that users recognise and abide by the legal requirements associated with these

- Users may download and print one copy of any publication from the public portal for the purpose of private study or research.

- You may not further distribute the material or use it for any profit-making activity or commercial gain

If the publication is distributed under the terms of Article $25 \mathrm{fa}$ of the Dutch Copyright Act, indicated by the "Taverne" license above, 


\title{
Voluntary Reporting on Internal Control by Listed Dutch Companies
}

\section{Rogier Deumes}

\author{
Maastricht University \\ Faculty of Economics and Business Administration \\ Maastricht Accounting and Auditing Research and Education Center \\ P.O. Box 616 \\ 6200 MD Maastricht \\ The Netherlands \\ Phone: $+31(0) 433883714$ \\ Fax: +31(0)433884876 \\ E-mail: r.deumes@berfin.unimaas.nl
}

MARC Working Paper MARC-WP/3/2000-04

Acknowledgements: The author is indebted to Steven Maijoor, Willem Buijink and Bill Felix for their insightful comments on previous versions of this paper. In addition, useful suggestions were received from Frank Moers, Caren Schelleman and Ann Vanstraelen. Special thanks go to Ivo Blij for providing access to his collection of companies' annual reports. 


\title{
Voluntary Reporting on Internal Control by Listed Dutch Companies
}

\begin{abstract}
This study investigates whether voluntary reporting on internal control by company management can be viewed as a monitoring mechanism that reduces conflicts of interest between management, shareholders and debtholders. An agency framework is used to analyse management's incentives for voluntary reporting on internal control. Empirical variables are chosen to proxy for external and internal agency costs. In addition, the effects of other monitoring mechanisms are tested. Multivariate tests are conducted on a sample of 149 listed Dutch companies for the year 1997. Reporting on internal control is voluntary in the Netherlands. The results indicate that voluntary reporting on internal control is significantly correlated with variables that proxy for the agency costs of equity (i.e. management ownership and the percentage of shares held by large investors), but is not correlated with variables that proxy for agency costs of debt (i.e. leverage and the proportion of assets in place). In addition, voluntary reporting on internal control is significantly correlated with company size.
\end{abstract}

Key Words: Internal Control, Internal Control Reporting, Monitoring Mechanisms

Data Availability: Contact the author 


\section{Introduction}

Reporting on internal control is an issue of considerable interest to policy makers involved in corporate governance issues. A fundamental assumption in public policy debates on this issue is that reporting on internal control improves the quality of financial reporting and reduces governance problems. If that is the case, reporting on internal control can been viewed as a monitoring mechanism that reduces conflicts of interest between management, shareholders and debtholders (i.e. agency costs). However, currently there is no empirical evidence regarding the association between agency costs and voluntary reporting on internal control. In this paper the hypothesis is tested whether voluntary reporting on internal control is used as a monitoring mechanism, by testing the effect of a selection of company characteristics on the extent of voluntary reporting on internal control by company management. The company characteristics proxy for agency costs. The extent of voluntary reporting on internal control will be measured in the annual statements of listed Dutch companies in 1997. The Dutch environment provides a suitable setting, because reporting on internal control is not required in the Netherlands.

The remainder of this paper is organised as follows. The next section presents a brief background on reporting on internal control and discusses previous empirical research in this area. Section 3 describes the theoretical framework used and develops the hypotheses to be tested. Section 4 details the research design. The results will be presented in section 5 . The final section summarises and concludes the paper. 


\section{Background and Previous Research}

Over the past decades, a diverse group of interested parties has claimed that reporting on internal control by companies improves their financial reporting and is beneficial to capital suppliers and other stakeholders. In this section, a background will be presented by briefly outlining the main arguments, recommendations and requirements for reporting on internal control in the United Kingdom, the United States and the Netherlands. Subsequently, previous empirical research on internal control reporting will be discussed.

\subsection{Background}

In the United Kingdom the Cadbury Committee (1992a) recommended that listed companies should report on the effectiveness of the company's system of internal control and that this report should be reviewed by the auditor. A working group of the Committee (Rutteman Committee 1994) provided guidance for directors on how they should report on internal control. The final report of the Hampel Committee (1998a) and its Combined Code (Hampel Committee 1998b) recommended that directors review the effectiveness of the internal control system and report to the shareholders that they have done so. The auditor should report on internal control privately to the directors. The Combined Code is supported by a compliance statement in the listing rules and a working party of the Committee (Turnbull Committee 1999) issued new guidance to implement the requirements relating to internal control and reporting on internal control.

In the United States, successively the Cohen Commission (1978), the Treadway Commission (1987), COSO (1992), the POB (1993) and the Board of Directors of the AICPA (1993) recommended that management of public companies should report on internal control. 
The Cohen Commission (1978), the POB (1993) and the AICPA (1993) went even one step further by suggesting that auditors should express an opinion on management's assertions regarding internal control. The Treadway Commission (1987) noted that the investing public has a legitimate interest in the extent of management's responsibilities for the company's financial statements and internal control. They stated that management's opinion on internal control is important because the internal control system provides the basis for the preparation of financial statements and more broadly, the overall system of accountability. Subsequently, COSO (1992) discussed in detail the internal control issues to report on. The POB (1993) and the AICPA (1993) both noted that increased auditor and top management involvement in reporting on internal control would improve the quality of financial reporting. Despite these strong views by various parties, the SEC has so far not required reporting on internal control ${ }^{1}$. In the Netherlands the Peters Committee (1997) has made a number of recommendations regarding reporting on internal control. Dutch companies have a two-tier board structure with an executive board of directors and a supervisory board. In accordance with Dutch law the supervisory board is 'bound by the interests of the company'. It is responsible for the supervision of management policy and the general course of affairs in the company. In the annual report of Dutch companies, a report of the supervisory board is included. The Peters Committee (1997) recommended that at least once a year the supervisory board should discuss the results of the assessment of the systems of internal control by the board of directors. The fact that such a discussion has been held (and not necessarily the content of the discussion) should be mentioned in the supervisory board's report in the company's annual report. They further recommended that the board of directors should report in writing to the supervisory board on the mechanisms used to control financial 
risks. The main items in this report should be a permanent part of the annual report. Compared to the United Kingdom and the United States, the recommendations of the Peters Committee (1997) are less extensive and detailed. Moreover, as in the United States, reporting on internal control is still voluntary in the Netherlands. In the United Kingdom stock exchange listing rules resulted in less freedom regarding reporting on internal control by requiring compliance to the Combined Code.

\subsection{Previous Research}

Considering the increased attention from various interested parties for reporting on internal control, relatively little empirical research has been done in this area. One of the first empirical studies in this field has been conducted by Raghunandan and Rama (1994). An analysis of the 1993 annual reports of Fortune 100 companies in the US revealed that 80 of the 100 companies included a management report on internal control and that the issues addressed in these reports were quite diverse. All of the 80 reports stated that the company maintained an internal control system in varying levels of detail. However, only six reports stated that the internal control system had been assessed to be effective.

McMullen et al. (1996) further investigated companies that are voluntarily reporting on internal control in a US environment. McMullen et al. (1996) argue that the control consciousness of management is a plausible reason for voluntary reporting on internal control. Given that reporting on internal control is not mandatory and that there may be nontrivial costs associated with reporting, they further argue that companies which are voluntarily reporting on internal control may be signalling their commitment to internal control to investors. Their study examined the possible usefulness of this signal by 
investigating the association between reporting on internal control and the absence of financial reporting problems. Financial reporting problems were defined as SEC enforcement actions and corrected previously reported earnings. The results indicated that, for smaller companies, there is an association between internal control reporting and the absence of financial reporting problems. According to McMullen et al. (1996) these results support the argument that, at least for smaller companies, reporting on internal control could be a useful signal. The study however does not provide further empirical evidence for the signalling argument as an explanation for voluntary reporting on internal control.

Hermanson (2000) documented the demand for internal control reporting by surveying several financial statement user groups in the US. Overall, the results indicated that the respondents agree that internal controls are important. They generally agreed that voluntary reporting on internal control motivates management to improve internal control, improves the oversight process of audit committees, and provides additional information for decision making. If reporting was mandatory the respondents felt less strongly about the informational value. The diminished informational value of mandatory reporting on internal control could mean that the respondents perhaps view voluntary reporting on internal control as a signal as suggested by McMullen et al. (1996).

\section{Theory and Hypotheses}

As pointed out in the previous section, a fundamental assumption in public policy debates and reports is that reporting on internal control improves the quality of financial reporting and reduces governance problems. In this section, agency theory will provide a framework for developing the hypotheses. Company management that chooses to report more extensively on 
internal control is hypothesized to be seeking a higher level of monitoring because of higher agency costs. To the extent possible, a distinction is made between internal and external agency costs.

\subsection{Agency Theory}

Internal agency costs arise from conflicting interests and information asymmetry between top managers and lower-level employees within the company. Management can reduce internal agency costs by monitoring subordinates' actions. A possible monitoring mechanism is the internal control system of the company (Abdel-khalik 1993). McMullen et al. (1996) give two reasons why reporting on internal control by company management can lead to enhanced internal controls. For both reasons reporting on internal control can be viewed as a monitoring mechanism that can help reduce internal agency costs. First, reporting on internal control can increase the internal control awareness of top management, which in turn can lead to greater attention being paid by top management to the internal control system in general. Second, reporting on internal control can lead to better internal controls because it helps to communicate the tone at the top by sending a clear message within the organisation about the expected control environment. Others also have noted that reporting on internal control can lead to better internal controls. The POB (1993) noted that company management will evaluate the internal control system before reporting on it and that evaluating the system will lead to improvements of the system.

External agency costs arise from conflicting interests and information asymmetry between management and shareholders, and between shareholders and debtholders (Jensen and Meckling 1976). Because financial accounting information plays an important role in 
contracting in defining contract terms and in monitoring the performance of contracts (Watts and Zimmerman 1986), a possible way for company management to reduce external agency costs is to improve the reliability of financial reporting. Reporting on internal control can improve the reliability of financial accounting information in two ways, and is therefore regarded in this study as a possible monitoring mechanism that can help reduce external agency costs. First, reporting on internal control can lead to enhanced internal controls as suggested by McMullen et al. (1996). Better internal controls in turn can lead to more reliable financial reporting. Second, McMullen et al. (1996) argue that companies, which are voluntarily reporting on internal control, might be signalling their commitment to internal control (i.e. the tone at the top) to investors. The tone at the top - the corporate control environment or culture within which financial reporting occurs - is an important factor contributing to the reliability of financial accounting information (Treadway Commission 1987).

As explained above, reporting on internal control is regarded in this study as a possible monitoring mechanism that can help reduce internal and external agency costs. Since Jensen and Meckling (1976) provided a framework of analysis based on agency relationships, many empirical studies have used this framework to analyse voluntary implementation of monitoring mechanisms by company management. Various monitoring mechanisms have been subject of study. Chow (1982) studied the demand for voluntary external auditing. Others have investigated quality differentiated external audits (e.g. Francis and Wilson 1988, DeFond 1992). Ettredge et al. (1994) analysed companies purchasing timely reviews by an external accountant. Carey et al. (2000) studied the monitoring role of internal and external auditing. The monitoring role of voluntary corporate disclosure has been studied by Leftwich 
et al. (1981), Chow and Wong-Boren (1987), and Craswell and Taylor (1992). Leftwich et al. (1981) investigated reporting frequency, Chow and Wong-Boren (1987) measured the extent of voluntary financial disclosures and Craswell and Taylor (1992) analyzed discretionary disclosure of reserves by oil and gas companies. Voluntary formation of audit committees for monitoring purposes has been examined by Pincus et al. (1989), Bradbury (1990), and Collier (1993). The monitoring role of audit committees has been further investigated by Menon and Williams (1994) and Collier and Gregory (1999). Menon and Williams (1994) investigated whether the board of directors relies on audit committees and Collier and Gregory (1999) investigated audit committee activities.

\subsection{Agency Conflict Hypotheses}

Company management that chooses to report more extensively on internal control is hypothesized to be seeking a higher level of monitoring because of higher internal and external agency costs. The variables used to proxy for agency costs are discussed below. Agency costs of equity and debt are considered to be external agency costs. Company size is associated with both external and internal agency costs.

\section{Agency costs of equity}

The first proxy for the agency costs of equity used in this study is management's ownership share of the company. Higher managent's ownership will lower the agency costs of equity because manager's and shareholders' incentives are more aligned (Jensen and Meckling 1976). This leads to the first hypothesis: 
$\mathrm{H}_{1}$ : Ceteris paribus, there is a negative association between management's ownership and the extent to which company management reports on internal control.

The second proxy for the agency cost of equity is the extent to which the shares of a company are held by small (individual), rather than large (institutional) investors. The net benefit of monitoring mechanisms implemented by company management may be higher for individual investors with small shareholdings as it is relatively more expensive and difficult for these investors to actively monitor management's activities themselves. Milgrom and Roberts (1992: 497) argue that larger shareholders are possibly more willing and able to play an active monitoring role. Following this argument, the agency costs of equity are lower if a company is owned by large investors. This will give company management less incentive to implement additional monitoring mechanisms. This leads to the second hypothesis:

$\mathrm{H}_{2}$ : Ceteris paribus, there is a negative association between the percentage of shares held by large investors and the extent to which company management reports on internal control.

\section{Agency costs of debt}

The first proxy for the agency cost of debt is leverage. Jensen and Meckling (1976) and others have suggested that higher leverage will increase agency costs because the potential for wealth transfers from debtholders to shareholders increases. This leads to the third hypothesis:

$\mathrm{H}_{3}$ : $\quad$ Ceteris paribus, there is a positive association between leverage and the extent to which company management reports on internal control. 
The second proxy for the agency cost of debt is the proportion of assets in place. According to Myers (1977) the value of the company can be seen as the sum of assets already in place and the present value of future investment opportunities. Wealth transfers between debtholders and shareholders are more difficult with assets already owned than assets yet to be acquired. This leads to the fourth hypothesis:

$\mathrm{H}_{4}$ : Ceteris paribus, there is a negative association between the proportion of assets in place and the extent to which company management reports on internal control.

\section{Company size}

Company size is associated with both external and internal agency costs. Chow (1982) states that external agency costs increase with company size as the amount of potential wealth transfers increases with company size. Abdel-khalik (1993) argues that internal agency costs increase with company size because of the increased risk of organisational loss of control in larger organisations. In addition, the marginal costs of implementing monitoring mechanisms are suggested to decrease with company size (Chow 1982). This leads to the fifth hypothesis:

$\mathrm{H}_{5}$ : Ceteris paribus, there is a positive association between company size and the extent to which company management reports on internal control.

\section{Other monitoring mechanisms}

Two monitoring mechanisms investigated in the previously mentioned studies on the voluntary implementation of monitoring mechanisms are considered here: the presence of an audit committee (Pincus et al. 1989, Bradbury 1990, Collier 1993, Menon and Williams 
1994, Collier and Gregory 1999) and audit quality (Francis and Wilson 1988, DeFond 1992). The extent of voluntary reporting on internal control being positively correlated with other monitoring mechanisms will support its complimentary nature, while a negative association will suggest that it functions as a substitute monitoring mechanism. Because the nature of the association is unclear, the following hypotheses are expressed in the null form:

$\mathrm{H}_{6}$ : Ceteris paribus, there is no association between the presence of an audit committee and the extent to which company management reports on internal control.

$\mathrm{H}_{7}$ : $\quad$ Ceteris paribus, there is no association between audit quality and the extent to which company management reports on internal control.

\subsection{Control Variable}

The Dutch stock exchange requires that companies with a foreign stock exchange listing provide the Dutch market with the same information as the foreign market. As discussed before, the stock exchange listing rules in the United Kingdom result in less freedom in the reporting choice on internal control and add some element of obligation by requiring stating compliance to the Combined Code. For this reason, management of companies with a listing at the London Stock Exchange is more likely to report on internal control in the annual report. This leads to the last hypothesis:

$\mathrm{H}_{8}$ : $\quad$ Ceteris paribus, there is a positive association between listing at the London Stock Exchange and the extent to which company management reports on internal control. 


\section{Research Design}

\subsection{Sample and Data Collection}

The sample used in this study consists of public Dutch companies that were listed on the Amsterdam stock exchange during 1997. Stocks listed at the Amsterdam Stock Exchange are actively traded. Investment funds, financial institutions (e.g. banks and insurance companies) and companies that had no two-tier board system were excluded from the sample. In addition, companies that were unlisted during 1997 were excluded. The final sample consisted of 149 companies. Data on the dependent variable were found in the company's annual report. Most data on the explanatory variables were available in the public Dutch databases 'REACH' and 'Het Financieel Economisch Lexicon'. In addition, data from the Dutch financial newspaper 'Het Financieele Dagblad' were used.

\subsection{Dependent Variable}

The extent to which company management voluntarily reports on internal control has been operationalised with an internal control reporting score (ICR). ICR was obtained by using a three-step process, which is described below. Measuring internal control reporting this way is similar to disclosure indices used in prior studies that investigated the association between company characteristics and disclosure level (e.g. Chow and Wong-boren 1987, Botosan 1997). Although these studies have shown that disclosure indices are a useful research tool, deriving a summated scale is difficult, as it requires subjective assessments by the researcher applying the technique. Therefore it is critical to assess the internal consistency of ICR and to examine the sensitivity of the results to alternative measures of ICR. 
The first step in determining ICR was to identify the items regarding reporting on internal control. By referring to the previously discussed public policy reports on corporate governance and internal control, a list of 8 separate reportable items was generated. The separate items are presented in the first column of table 1, and are discussed below. The first three items have been derived from the recommendations regarding internal control made by the Dutch Committee on Corporate Governance (Peters Committee 1997). The remaining items have been derived from public policy reports in the United States (COSO 1992) and the United Kingdom (Cadbury Committee 1992a, Hampel Committee 1998a and Turnbull Committee 1999). The Peters report was published in 1997 and company management had the opportunity to comply with the recommendations in their 1997 annual report. Although the Hampel Committee report and the Turnbull guidance were published after 1997, their recommendations and guidance were based on public opinions developed earlier and on actual reporting practices in previous years. This makes it possible that companies reported the recommended information in 1997.

Item 1. As discussed before, the Peters Committee (1997) recommended that at least once a year the supervisory board should discuss the results of the assessment of the systems of internal control by the board of directors. The fact that such a discussion has been held (and not necessary the content of the discussion) should be mentioned in the supervisory board's report in the company's annual report. Typically, the supervisory board reported on this item by stating that 'in our meetings attention was paid to the internal control system'.

Item 2. Another recommendation made by the Peters Committee (1997) was that the supervisory board should meet with the external auditor at least once a year. Item 2 represents the fact that the supervisory board mentions that such a meeting was held and that certain 
elements of the internal control system were discussed during this meeting. Usually, the supervisory board reported on this item by stating that 'in the presence of the external auditor, the internal control system was discussed'.

Item 3. The Peters Committee (1997) further recommended that the board of directors should report in writing to the supervisory board on the mechanisms used to control financial risks. The main issues in this report should be a permanent part of the annual report. Commonly, the board of directors reported on this item by stating that 'the board of directors reports in writing to the supervisory board on the mechanisms used to control financial risk'.

Item 4. COSO (1992) stated that the internal control system is designed to provide reasonable assurance regarding the achievement of objectives in the following categories: efficiency and effectiveness of operations, reliability of financial reporting, and compliance with laws and regulations. Consequently, COSO (1992) suggests that management should state whether an internal control system has been established to achieve these objectives. The Hampel Committee (1998a) stated that a company's system of internal control safeguards shareholder's and company's assets. In addition, the Turnbull Committee (1999) mentions that internal control is one of the principal elements in the management of risks and the fact that there is an on-going process for identifying, evaluating and managing company's risk should be reported in the annual report. This leads to including item 4, which is valued one if the board of directors stated the objectives of their internal control system in the annual report. Frequently reported objectives of the internal control system were control of risk associated with the business activities, controlling the effectiveness and efficiency of the business activities, safeguarding of assets, compliance with laws and regulation, and reliable management and financial reporting. 
Item 5. COSO (1992), the Cadbury Committee (1992a) and the Hampel Committee (1998a) have emphasised management's responsibilities for internal control and recommended that management makes a statement on their responsibilities in the annual report. According to COSO (1992) management should state that it is responsible for devising and maintaining a system of internal control. The Turnbull Committee (1999) recommended that the board of directors' disclosures should include an acknowledgement by the board that it is responsible for the internal control system and for reviewing its effectiveness. Most companies reporting on the responsibility for the internal control system stated that 'within the framework established by the board of directors, operational management is responsible for the functioning of the internal control system'.

Item 6. Another approach for management to discuss its responsibilities is to state its belief as to whether it has fulfilled specific responsibilities (COSO 1992). Management might for example address the effectiveness or the adequacy of the company's internal control system. The Cadbury Committee (1992a) also made this recommendation. The Hampel Committee (1998a) encouraged directors to report on the effectiveness but did not require stating an opinion. Generally, companies reporting on item 6 stated that the board of directors considers the internal control system to be adequate'.

Item 7. The Turnbull Committee (1999) considered information on how management makes use of the work of the internal auditor to be important as it provides information on how the board of directors has reviewed the effectiveness of the system. COSO (1992) also recommended discussing the program of internal auditing. Companies reporting on this item often stated that 'the internal auditors monitor the internal control system and report their findings to the board of directors'. 
Item 8. Discussion of specific elements of internal control has been recommended by COSO (1992). According to the Turnbull Committee (1999) the board of directors may wish to provide additional information in the annual report to assist understanding of the company's risk management processes and system of internal control. Most companies reporting on this item discussed specific controls used for managing risk.

\section{[Insert Table 1 Here]}

The second step in determining ICR was closely examining the annual report of each company in the sample and identifying the presence of each item. The number and percentage of companies in the sample reporting on each item are shown in table 1.

The third step taken was to calculate an unweighted score for each company in the sample by summing the individual items company management reported on. This implies that all items are considered to be equally important in reporting on internal control. The resulting variable ICR ranks the extent to which company management voluntarily reports internal control items and is therefore treated in this study as an ordered variable. Section 5.4 discusses the sensitivity of the results for the items included in ICR.

\subsection{Explanatory Variables}

The explanatory variables follow from the hypotheses developed in section 3 . The measurement of each variable is stated below.

$H_{1}$ - Management's ownership (MO). In the Netherlands it is not required to report the percentage of shares held by company management in the annual report. Owners of more 
than $5 \%$ of the shares of a listed company however are required to report their share of ownership to the Dutch stock exchange supervisor 'Stichting Toezicht Effectenverkeer' (Securities Board of the Netherlands). Because this data is publicly available, it was possible to compare the names of these shareholders with the names of the members of the board of directors and calculate management's ownership by adding up the percentage of shares held by members of the board of directors. As a result of this, management shareholdings smaller than $5 \%$ are not accounted for. $H_{2}$ - Percentage of shares held by large investors (LI). Using the data reported to the Dutch stock exchange supervisor, the percentage of shares owned by large investors was calculated by adding up the percentages of shareholdings of nonmanagers greater than $5 \%$ (i.e. shareholdings of less than $5 \%$ are considered to be small investors). $H_{3}$ - Leverage ( $L E V$ ). Leverage is measured here as the ratio of the book value of debt to the sum of the market value of equity and the book value of debt. $H_{4}$ - Proportion of assets in place (AIP). The proportion of assets in place is measured here by the ratio of the book value of fixed assets to the sum of the market value of equity and the book value of debt. $H_{5}$ - Company size (SIZE). Company size is measured in this study as the natural logarithm of the sum of the market value of equity and the book value of debt. $H_{6}$ - Presence of an audit committee (AC). The presence of an audit Committee is measured by a dummy variable, which is set to one if the supervisory board has formed an audit committee from among its members. $H_{7}$ - Audit quality $(A Q)$. Audit quality is measured by a dummy variable, which is set to one if the company's financial statements are audited by a Big 5 auditor. $H_{8}$ Listing at the London Stock Exchange (LSE). This is a dummy variable, which is set to one if a company is listed at the London Stock Exchange. 


\title{
5. Results
}

\subsection{Descriptive Statistics and Univariate Tests}

Table 2 contains descriptive data for the variables in the model. Most variables are skewed and have high kurtosis. In addition, Kolmogorov-Smirnov one-sample tests showed that the assumption about the normality of the distribution for all variables except SIZE could be rejected at conventional probability levels $(p<.05)$.

ICR's average value of 1.6 is quite low. The highest observed value of ICR is 6, which means that none of the 149 companies reported on all 8 items listed in table 1 . More specifically, 40 (27\% of 149$)$ companies reported on none of the items, $38(26 \%)$ reported on 1 item, $40(27 \%)$ reported on 2 items, $16(11 \%)$ reported on 3 items, $5(3 \%)$ reported on 4 items, $7(5 \%)$ reported on 5 items, and $3(2 \%)$ reported on 6 items. As a result, ICR is ranked from 0 to 6 in further analysis.

Several tests were carried out to assess the internal consistency of ICR. The correlation coefficients of each item to the total score are all positive and statistically significant at the $1 \%$ level. Most correlation coefficients among items are statistically significant at the 5\% level. Cronbach's alpha is .67 . The generally agreed lower limit for Cronbach's alpha is .70, although it may decrease to .60 in exploratory research (Robinson et al. 1991). This means that random measurement error could reduce the power of the empirical tests that follow ${ }^{2}$.

\author{
[Insert Table 2 Here]
}


Table 3 presents pairwise Spearman correlations among the variables used in the model. Kendall's tau, another nonparametric measure of association, yielded identical results for both direction and significance of all reported correlation coefficients ${ }^{3}$. The Spearman correlations between ICR and the explanatory variables in the first row provide a univariate test for each explanatory variable. Two-tailed probabilities were calculated for AQ and AC, as no association has been hypothesised between ICR and these variables. The univariate results show that the explanatory variables, except those which proxy for agency costs of debt, are significantly correlated with ICR $(p<.05)$ in the direction hypothesised. LEV and AIP are not significantly correlated with ICR and the direction of the correlation between AIP and ICR is contrary to that hypothesised.

\section{[Insert Table 3 Here]}

\subsection{Multivariate Test}

The lower triangular in table 3 presents Spearman correlations among the explanatory variables. Many significant correlations exist and the degree of correlation suggest that the results of the univariate tests may be overstated. A multivariate test is an appropriate means to consider simultaneous effects of the explanatory variables on ICR. While in general there is little indication of multi-collinearity present, consistent with Leftwich et al. (1981) the correlation coefficient between LEV and AIP is quite high (.74 and significant at the $1 \%$ level, two-tailed). For this reason first LEV and then AIP were excluded in multivariate testing. These tests yielded identical results for both the direction and the significance of all 
coefficients in the model, which suggests that the high correlation has no material consequences for the multivariate results reported below.

The multivariate technique used in this study is ordered logit analysis ${ }^{4}$. The ordered logit model takes into account the ordinal nature of ICR and makes no assumptions regarding the distribution of the explanatory variables ${ }^{5}$. The estimated coefficients of an ordered logit analysis however must be interpreted with care (Greene 2000: 878) ${ }^{6}$.

Table 4 shows the results of the ordered logit analysis. Two-tailed probabilities were calculated for AQ and AC, as no association has been hypothesised between ICR and these variables.

\section{[Insert Table 4 Here]}

The maximised value of the log-likelihood function is -217.41 and the value of the model's likelihood ratio statistic is $51.02(8 d f)$, meaning that the null hypothesis of no statistical association can be rejected at the .00 level of confidence. The likelihood ratio index is an analog to the $\mathrm{R}^{2}$ of a conventional regression and measures the ordered logit model's goodness of fit. The value of the likelihood ratio index is $10.1 \%$.

The results of the ordered logit analysis show that both variables that proxy for agency costs of equity are significantly correlated with ICR in the direction hypothesised. The percentage of shares owned by company management (MO) is significantly correlated with ICR at the $1 \%$ level and the percentage of shares held by large investors (LI) is significantly correlated at the $5 \%$ level. However, no significant correlation was found between ICR and the variables that proxy for agency costs of debt. Although the sign of the coefficients of the 
leverage variable (LEV) and assets in place (AIP) are both in the direction hypothesised, the coefficients are not significant. The results further show that company size (SIZE) is significantly correlated $(p<.05)$ in the direction hypothesised (i.e. positive). The association between other monitoring mechanisms and ICR is weak. The existence of an audit committee (AC) and audit quality (AQ) are both positively correlated (i.e. complementary monitoring mechanisms), but the coefficient of $\mathrm{AC}$ is not significant and the significance level of the coefficient of AQ is only moderate $(p<.10)$.

Finally, the control variable for listing at the London Stock Exchange (LSE) has a significant positive effect on ICR $(p<.01)$. This indicates that management as a result of listing rules in the UK reports more extensively on internal control and provides the Dutch market with the same information ${ }^{7}$.

\subsection{Alternative Tests}

The simultaneous effect of the explanatory variables on ICR has also been tested using OLS regression. The OLS model estimated was also highly significant $(p<.00)$ and had a $\mathrm{R}^{2}$ of 27.1\%. Direct comparison of the $\mathrm{R}^{2}$ of the OLS model and the Pseudo- $\mathrm{R}^{2}$ of the ordered logit model however, is not possible. The regression coefficients estimated lead to identical conclusions. In addition to these regression estimates, bootstrapped estimates of the OLS model were calculated. Bootstrapping does not rely on a single model estimation but instead calculates parameter estimates and their confidence intervals based on multiple observations. The results of bootstrap resampling are similar to direct estimation and lead to identical conclusions. 


\subsection{Sensitivity of the Results}

Obtaining an internal control reporting score (ICR) is difficult because deciding which items should be included in calculating the score requires subjective judgement. ICR tested in the previous sections was based on all 8 reportable items identified (see table 1). By one-for-one excluding each item from the original score, the sensitivity of the results of the ordered logit analysis for the items included in the score was tested ${ }^{8}$.

The results of this sensitivity test show that the coefficients of MO, LI and LSE remain significant $(p<.05)$. The coefficient of SIZE remains significant as long as item 8 is included in the score. If item 8 is excluded from the score, the coefficient of SIZE becomes moderately significant $(p<.10)$. Comparing the goodness of fit gives an indication of the impact of item 8 . The likelihood ratio indices remain approximately $10 \%$ if item 8 is included in the score. If item 8 is excluded, the likelihood ratio index drops to $8 \%$. Overall, the sensitivity analyses show that the results presented in previous sections are not driven by a single item included in the score.

\section{Summary and Conclusions}

Reporting on internal control by company management has been frequently recommended as a possible way to improve financial reporting and reduce governance problems. Using a sample of 149 listed Dutch companies, this study finds that the extent of voluntary reporting on internal control varies considerably between companies. In this study company management that chooses to report more extensively on internal control is hypothesized to be seeking a higher level of monitoring because of higher external and internal agency costs. Overall, the results lend support to this hypothesis. 
The results show that there is a positive association between firm size, a proxy for both external and internal agency costs, and the extent to which company management voluntarily reports on internal control. Reporting on internal control is also found to increase with variables that proxy for agency costs of equity. This is consistent with the argument that voluntary reporting on internal control enables company management to improve the quality of financial reporting. Agency problems related to debt financing, however, do not appear to affect voluntary reporting on internal control. This might indicate that debtholders have alternative ways to establish the importance given by top management to the issue of internal control. The results further weakly suggest that reporting on internal control is complementary to other monitoring mechanisms. Both univariate and multivariate tests show a positive correlation, but only the univariate results are significant. Finally, the results show that Dutch companies listed on the London Stock Exchange report more extensively on internal control. It is argued that these companies have less freedom in their reporting choice.

In all, these results show that there is an economic basis for the decision to report on internal control. The results therefore do not to appear to point to a need for extensive government regulation in this area. Mandating reporting on internal control could cause companies with lower agency costs to overspend on monitoring. Mandatory reporting on internal control would also remove the signalling aspect (see section 3.1). However a caveat is in order here. This caveat concerns the overall explanatory power of the multivariate analyses (both ordered logit and OLS). Holding aside potential measurement error problems, the agency variables appear to affect voluntary reporting on internal control only moderately. Managements' decision to report on internal control appears to be more complex than modelled in this study. 
TABLE 1

Internal control reporting items, and

the number (\%) of companies reporting on these items

$(n=149)$

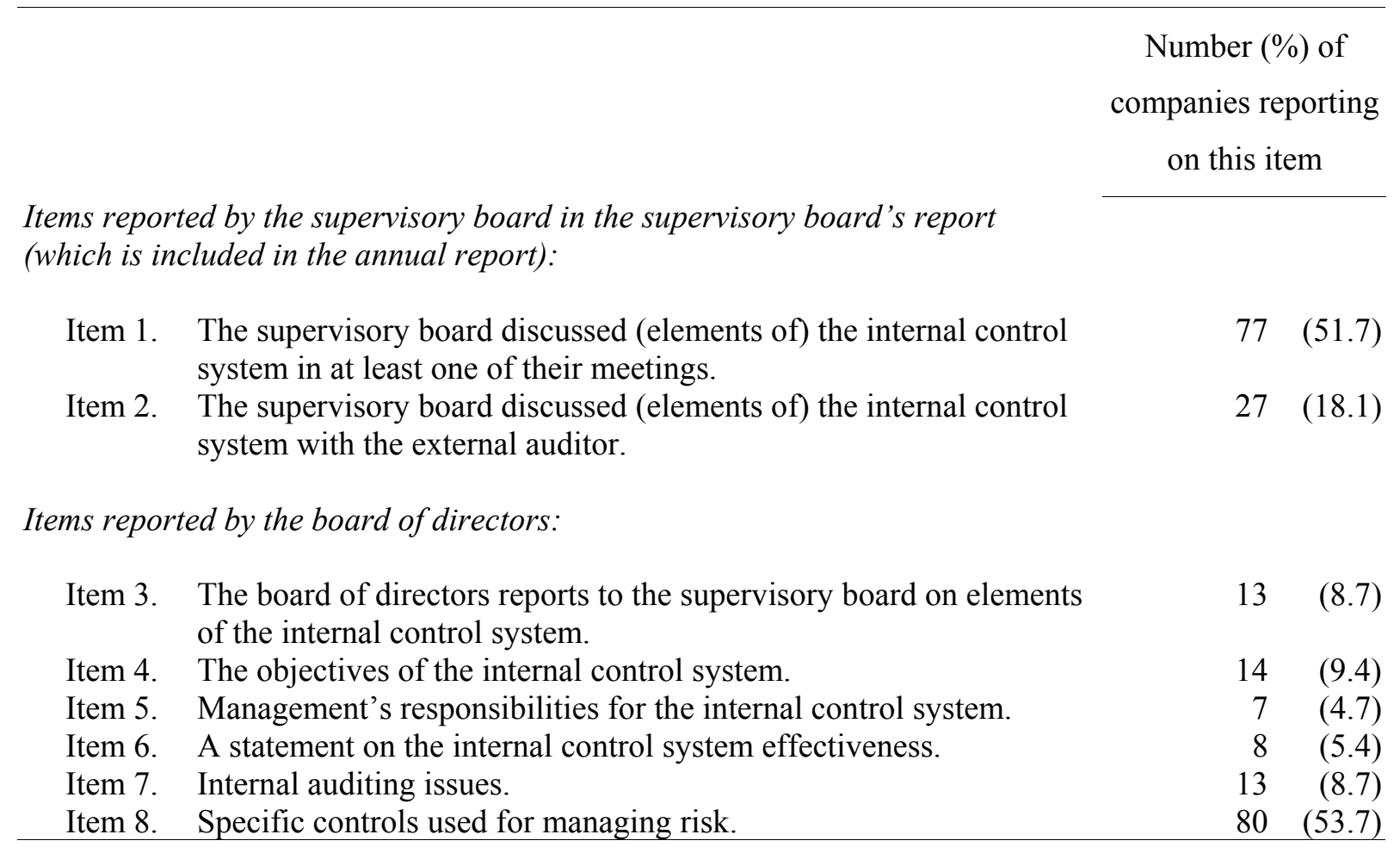


TABLE 2

Descriptive statistics

$(n=149)$

\begin{tabular}{lrrrrrrr}
\hline & Mean & Median & S.D. & Min. & Max. & Skewness & Kurtosis \\
\cline { 2 - 7 } AGENCY VARIABLES & & & & & & & \\
Management Ownership (MO) & 4.88 & .00 & 15.05 & .00 & 88.22 & 3.56 & 12.62 \\
Large Investors (LI) & 37.46 & 33.38 & 27.19 & .00 & 100.00 & .44 & -.80 \\
Leverage (LEV) & .86 & .58 & 1.15 & .02 & 11.56 & 6.02 & 50.90 \\
Assets in Place (AIP) & .64 & .38 & .86 & .01 & 8.01 & 5.00 & 37.35 \\
Company Size (SIZE & 19.81 & 19.70 & 1.98 & 15.55 & 26.20 & .42 & .00 \\
Audit Committee (AC) & .13 & .00 & .34 & .00 & 1.00 & 2.17 & 2.74 \\
Audit Quality (AQ) & .95 & 1.00 & .23 & .00 & 1.00 & -4.00 & 14.19 \\
CONTROL VARIABLE & & & & & & & \\
London Stock Exchange (LSE) & .06 & .00 & .24 & .00 & 1.00 & 3.73 & 12.06 \\
DEPENDENT VARIABLE & & & & & & & \\
Internal Control Reporting (ICR) & 1.60 & 1.00 & 1.47 & .00 & 6.00 & 1.01 & .73 \\
\hline
\end{tabular}

${ }^{*} \mathrm{MO}=$ percentage of shares held by company management; LI = percentage of shares held by large investors; $\mathrm{LEV}=$ ratio of the book value of total debt to the sum of the market value of equity and the book value of debt; AIP = ratio of the book value of fixed assets to the sum of the market value of equity and the book value of debt; SIZE = natural logarithm of the sum of the market value of equity and the book value of debt; $\mathrm{AC}=$ dummy variable which is set to one if the supervisory board has formed an audit committee; $A Q=$ dummy variable which is set to one if the company's financial statements are audited by a Big 5 auditor; LSE = dummy variable which is set to one if a company is listed at the London Stock Exchange; ICR = score that measures the extent of voluntary reporting on internal control by company management. 
TABLE 3

Spearman correlations among variables

\begin{tabular}{lcccccccc}
\hline & MO & LI & LEV & AIP & SIZE & AC & AQ & LSE \\
\hline ICR & $-.23^{a}$ & $-.14^{b}$ & .10 & .13 & $.43^{a}$ & $.30^{c}$ & $.21^{d}$ & $.34^{a}$ \\
MO & 1.00 & & & & & & & \\
LI & $-.33^{c}$ & 1.00 & & & & & & \\
LEV & $-.18^{d}$ & $.20^{d}$ & 1.00 & & & & & \\
AIP & $-.25^{c}$ & .14 & $.74^{c}$ & 1.00 & & & & \\
SIZE & -.13 & $-.20^{d}$ & $-.23^{c}$ & -.08 & 1.00 & & & \\
AC & -.12 & -.05 & .03 & .12 & $.40^{c}$ & 1.00 & & \\
AQ & -.07 & -.03 & .16 & $.16^{d}$ & $.22^{c}$ & .09 & 1.00 & \\
LSE & -.11 & -.13 & -.07 & .07 & $.35^{c}$ & $.31^{c}$ & .06 & 1.00 \\
\hline
\end{tabular}

* ICR = Internal Control Reporting; $\mathrm{MO}=$ Management Ownership; LI = Large Investors; LEV = Leverage; $\mathrm{AIP}=$ Assets in Place; SIZE = Company Size; $\mathrm{AC}=$ Audit Committee; $\mathrm{AQ}=$ Audit Quality; LSE $=$ London Stock Exchange.

${ }^{a}$ Significant at the .01 level (one-tailed).

${ }^{b}$ Significant at the .05 level (one-tailed).

${ }^{c}$ Significant at the .01 level (two-tailed).

${ }^{d}$ Significant at the .05 level (two-tailed). 
TABLE 4

Ordered logit analysis of the association between

the explanatory variables and Internal Control Reporting (ICR)

$(n=149)$

\begin{tabular}{clrrr}
\hline Hypothesis & Variables & Predicted sign & $\beta$-Coefficient & z-Statistic \\
\hline \multicolumn{2}{c}{ AGENCY VARIABLES } & & & \\
$\mathrm{H}_{1}$ & Management Ownership (MO) & - & -.031 & $-2.658^{a}$ \\
$\mathrm{H}_{2}$ & Large Investors (LI) & - & -.011 & $-1.740^{b}$ \\
$\mathrm{H}_{3}$ & Leverage (LEV) & + & .213 & .810 \\
$\mathrm{H}_{4}$ & Assets in Place (AIP) & - & -.358 & -1.054 \\
$\mathrm{H}_{5}$ & Company Size (SIZE & + & .224 & $2.230^{b}$ \\
$\mathrm{H}_{6}$ & Audit Committee (AC) & $?$ & .603 & 1.287 \\
$\mathrm{H}_{7}$ & Audit Quality (AQ) & $?$ & 1.591 & $1.814^{c}$ \\
$\mathrm{CONTROL} \mathrm{VARIABLE}_{\mathrm{H}_{8}}$ & London Stock Exchange (LSE) & + & & \\
& & & 1.586 & $2.365^{a}$ \\
& Log likelihood & & -217.41 & \\
& LR statistic (8df) & & 51.02 & $(\mathrm{p}=.00)^{a}$ \\
\hline
\end{tabular}

${ }^{a}$ Significant at the .01 level (one-tailed).

${ }^{b}$ Significant at the .05 level (one-tailed).

${ }^{c}$ Significant at the .10 level (two-tailed). 


\section{References}

Abdel-khalik, A. R. (1993). 'Why do private companies demand auditing? A case for organisational loss of control'. Journal of Accounting, Auditing and Finance, 8(1): $31-52$.

AICPA (American Institute of Certified Public Accountants). 1993. Meeting the Financial Reporting Needs of the Future: A Public Commitment from the Public Accounting Profession. New York: AICPA.

Aitchison, J. and Silvey, S. D. (1957). 'The generalization of probit analysis to the case of multiple responses'. Biometrika, 44: 131-140.

Ball, R. and Foster, G. (1982). 'Corporate financial reporting: A methodological review of empirical research'. Journal of Accounting Research, 20 (supplement): 161-284.

Botosan, C. A. (1997). 'Disclosure level and the cost of equity capital'. The Accounting Review, 72(3): 232-349.

Bradbury, M. E. (1990). 'The incentives for voluntary audit committee formation'. Journal of Accounting and Public Policy, 9(1): 19-36.

Cadbury Committee (Committee on the Financial Aspects of Corporate Governance) (1992a). Report of the Committee on the Financial Aspects of Corporate Governance. London: Burgess Science Press.

Cadbury Committee (Committee on the Financial Aspects of Corporate Governance) (1992b). Code of Best Practice. UK.

Carey, P., Simnett, R. and Tanewski, G. (2000). 'Voluntary demand for internal and external auditing by family businesses'. Working Paper. Monash University.

Chow, C. W. (1982). 'The demand for external auditing: size, debt and ownership influences'. The Accounting Review, 57(2): 272-291.

Chow, C. W. and Wong-Boren, A. (1987). 'Voluntary financial disclosure by Mexican corporations'. The Accounting Review, 62(3): 533-541.

Cohen Commission (Commission on Auditor's Responsibilities) (1978). Report, Conclusions, and Recommendations. New York: AICPA. 
Collier, P. (1993). 'Factors affecting the formation of audit committees in major UK listed companies'. Accounting and Business Research, 23(91A): 421-430.

Collier, P. and Gregory, A. (1999). 'Audit committee activity and agency costs'. Journal of Accounting and Public Policy, 18(4-5): 311-332.

COSO (Committee of Sponsoring Organisations of the Treadway Commission) (1992). Internal Control - Integrated Framework. New York: AICPA.

Craswell, A. T. and Taylor, S. L. (1992). 'Discretionary disclosure of reserves by oil and gas companies: An economic analysis'. Journal of Business, Finance and Accounting, 19(2): 295-308.

DeFond, M. L. (1992). 'The association between changes in client firm agency costs and auditor switching'. Auditing: A Journal of Practice and Theory, 11(1): 16-31.

Ettredge, M., Simon, D., Smith, D. and Stone, M. (1994). 'Why do companies purchase timely quarterly reviews?'. Journal of Accounting and Economics, 18(2): 131-155.

Francis, J. R. and Wilson, E. A. (1988). 'Auditor changes: a joint test of theories relating to agency costs and auditor differentiation'. The Accounting Review, 63(4): 663-682.

Greene, W. H. (2000). Econometric Analysis. Fourth edition. Upper Saddle River, NJ: Prentice-Hall.

Hampel Committee (Committee on Corporate Governance) (1998a). Final Report of the Committee on Corporate Governance. London: Gee Publishing.

Hampel Committee (Committee on Corporate Governance) (1998b). Combined Code. UK.

Hermanson, H. M. (2000). 'An analysis of the demand for reporting on internal control'. Accounting Horizons, 14(3): 325-341.

Jensen, M. and Meckling, W. (1976). 'Theory of the firm: managerial behaviour, agency costs and ownership structure'. Journal of Financial Economics, 3(4): 305-360.

Leftwich, R. W., Watts, R. L. and Zimmerman, J. L. (1981). 'Voluntary corporate disclosure: The case of interim reporting'. Journal of Accounting Research, 19 (supplement): 5077.

McMullen, D. A., Raghunandan, K. and Rama, D. V. (1996). 'Internal control reports and financial reporting problems'. Accounting Horizons, 10(4): 67-75. 
Menon, K. and Williams, J. D. (1994). 'The use of audit committees for monitoring'. Journal of Accounting and Public Policy, 13(2): 121-139.

Milgrom, P. and Roberts, J. (1992). Economics, Organization and Management. Englewood Cliffs, NJ: Prentice-Hall.

Myers, S. C. (1977). 'Determinants of corporate borrowing'. Journal of Financial Economics, 5(2): 147-175.

Peters Committee (Committee on Corporate Governance) (1997). Recommendations on Corporate Governance in the Netherlands. Amsterdam: Secretariat Corporate Governance.

Pincus, K., Rusbarsky, M. and Wong, J. (1989). 'Voluntary formation of corporate audit committees among NASDAQ firms'. Journal of Accounting and Public Policy, 8(4): 239-265.

POB (Public Oversight Board) (1993). In the Public Interest. Stamford: POB.

Raghunandan, K. and Rama, D. V. (1994). 'Management reports after COSO'. Internal Auditor, 51(4): 54-59.

Robinson, J. P., Shaver, P. R. and Wrightsman, L. S. (1991). Measures of Personality and Social Psychological Attitudes. San Diego, CA: Academic Press.

Rutteman Committee (Working Group of the Committee on the Financial Aspects of Corporate Governance) (1994). Internal Control and Financial Reporting: Guidance for Directors of Listed Companies. UK.

Solomon, M. B. and Cooper, J. R. (1990). 'Reporting on internal control: The SEC's proposed rules'. Journal of Accountancy, 169(6): 56-63.

Treadway Commission (National Commission on Fraudulent Financial Reporting) (1987). Report of the National Commission on Fraudulent Financial Reporting. New York: NCFFR.

Turnbull Committee (Working Party of the Committee on Corporate Governance) (1999). Internal Control: Guidance for Directors on the Combined Code. London: ICAEW.

Watts, R. L. and Zimmerman, J. L. (1986). Positive Accounting Theory. Englewood Cliffs, NJ: Prentice-Hall. 


\section{Endnotes}

${ }^{1}$ Although the SEC attempted to mandate reporting on internal control in 1979 and 1988, it failed to do so (Solomon and Cooper 1990).

${ }^{2}$ Botosan (1997), who used a disclosure index to investigate the determinants of corporate disclosure, reported a Cronbach coefficient alpha of .64.

${ }^{3}$ Only nonparametric measures of association are appropriate here because the dependent variable ICR is treated as an ordered variable and both the dependent and explanatory variables (except SIZE) have non-normal distributions.

${ }^{4}$ Following the work of Aitchison and Silvey (1957) the ordered logit model is set up as follows: $y^{*}=\beta{ }^{\prime} x+\varepsilon$; where $y^{*}$ is the unobserved dependent variable, $x$ is a vector of explanatory variables, $\beta$ is an unknown parameter vector, and $\varepsilon$ represents the error term which is caused by unobserved factors. Instead of $y^{*}$ the following is observed: $y=0$ if $y^{*} \leq \mu_{1} ; y=1$ if $\mu_{1} \leq y^{*} \leq \mu_{2} ; y=2$ if $\mu_{2} \leq y^{*} \leq \mu_{3} ; \ldots ; y=6$ if $\mu_{6} \leq y^{*}$; where $\mu$ is a vector of unknown threshold values that is estimated with the $\beta$ vector. The error term $\varepsilon$ is assumed to have a standard logistic distribution. The probability of observing each value of $y$ is calculated as follows: $\operatorname{Prob}(\mathrm{y}=\mathrm{k})=$ $\Phi\left(\mu_{k+1}-\beta\right.$ 'x $)-\Phi\left(\mu_{k}-\beta^{\prime} x\right)$; where $\Phi$ is the cumulative distribution function of $\varepsilon$. The probabilities of observing each value of $y$ are used to derive a $\log$ likelihood function. Estimates of $\beta$ and $\mu$ are obtained by maximising the $\log$ likelihood function.

${ }^{5}$ Although the outcome of ICR is discrete, multinomial logit analysis would fail to account for the ordinal nature of this variable. Ordinary regression on the other hand would treat the difference between a score of 0 and 1 , the same as the difference between a score of 1 and 2, whereas in fact they are only a ranking (Greene 2000: 875). In addition, all variables except SIZE have a non-normal distribution. Ordinary regression requires that for each value of the independent variable, the distribution of the dependent variable is normal.

${ }^{6}$ The derivative of $\operatorname{Prob}(\mathrm{y}=0)$ has the opposite direction sign from the coefficient estimate and the derivative of $\operatorname{Prob}(y=6)$ has the same sign as coefficient estimate. The signs of the changes in the other probabilities are ambiguous as for each probability the marginal effect of changes in $\mathrm{x}$ is equal to $\left[\partial \Phi\left(\mu_{\mathrm{k}+1}-\beta^{\prime} \mathrm{x}\right) / \partial \mathrm{x}\right]-\left[\partial \Phi\left(\mu_{\mathrm{k}^{-}}\right.\right.$ $\beta \prime x) / \partial x]$.

${ }^{7}$ Additional tests were conducted for foreign stock exchange listings at stock exchanges with no explicit listing requirements regarding reporting on internal control (e.g. New York). These listings had no significant effect on ICR.

${ }^{8}$ To prevent possible problems of multi-collinearity caused by the relative high correlation between the LEV and AIP, both variables were included separately in the ordered logit models tested in this section. The results of the ordered logit analysis with LEV instead of AIP are discussed here. The results of ordered logit analysis with AIP instead of LEV are similar and lead to identical conclusions. 